\title{
Postharvest Quality of Noble and Nordmann Fir Christmas Trees
}

\author{
Gary A. Chastagner ${ }^{1}$ and Kathleen L. Riley \\ Washington State University, Research and Extension Center, Puyallup, \\ WA 98371
}

\section{Additional index words. Abies procera, Abies nordmanniana}

\begin{abstract}
Moisture and needle loss characteristics were similar for noble (Abies procera Red.) and Nordmann fir [Abies nordmanniana (Stev.) Spach.] Christmas trees that were displayed in water. After 42 days, trees still had xylem pressure potentials above -2 MPa. In addition, trees that were displayed in water had very little needle loss. When trees were displayed dry, noble and Nordmann fir had similar rates of moisture loss, drying to about $-6 \mathrm{MPa}$ in about 3 weeks. Although there was very little needle loss from any of the noble fir trees that were displayed dry, some Nordmann fir trees began to shed large numbers of green needles within 3 to 5 days, which significantly reduced postharvest quality. Unless sources of Nordmann fir are identified that have good needle retention characteristics, the needle loss problem observed when trees dry to about $-3 \mathrm{MPa}$ has the potential to limit the use of this species as a Christmas tree in the United States.
\end{abstract}

Noble fir is one of the most important conifer species used for the production of high-quality Christmas trees in the Pacific Northwest (PNW).

The PNW supplies about one-third of the 36 million Christmas trees sold annually in the United States, and noble fir now accounts for about $45 \%$ of the total production in the PNW (Chastagner and Benson, 2000). Although demand for Christmas trees with excellent needle and moisture retention is high, expansion of noble fir production is limited to certain sites because of its susceptibility to a number of diseases (Chastagner and Benson, 2000).

Nordmann fir is native to the Caucasus Mountains along the eastern edge of the Caspian Sea in the Republic of Georgia and Turkey (Bean, 1981; Løfting 1973). Greenhouse studies (Benson et al., 1998; Chastagner et al., 1990) and grower observations in the PNW indicate that this species is less susceptible to some diseases, such as Phytophthora root rot and current season needle necrosis, that can limit where noble fir Christmas trees can be grown in the PNW. Consequently, there is increasing interest in growing this species in the PNW, particularly on sites where diseases limit the production of noble fir.

Nordmann fir is an important Christmas tree in Europe (Frampton and McKinley, 1999), where it is considered to have high-quality foliage and needle retention characteristics (Jakobsen, 1988). Europeans prefer unsheared, natural-looking trees, and Nordmann fir serves this purpose very well. Unlike the United

Received for publication 11 April 2002. Accepted for publication 22 July 2002. Plant Pathology New Series No. 0339, Dept. of Plant Pathology, College of Agriculture and Home Economics, Washington State Univ., Pullman, WA 99164-6430. The Pacific Northwest Christmas Tree Association supported portions of this work. The donation of trees by Del and Barbara Hupp and the assistance of Valerie McQuarrie-Baker are gratefully acknowledged.

${ }^{1}$ To whom reprint requests should be sent. E-mail address: chastag@wsu.edu
States, where trees may be displayed for 4 weeks or more, Europeans tend to limit the length of time Christmas trees are displayed indoors to a few days around Christmas day. For Nordmann fir to be a suitable alternative for noble fir in North American markets, a better understanding of its postharvest characteristics is needed. The objective of this study was to compare the postharvest moisture and needle retention characteristics of Nordmann fir with those of noble fir.

\section{Materials and Methods}

Whole-tree postharvest experiments were conducted in 1994 and 1995. Ten noble fir (440 seed zone) and 10 Nordmann fir (unspecified Georgian seed zone) Christmas trees growing in areas adjacent to each other were harvested from a commercial grower's field in Oregon on 14 Nov. 1994 and 24 Nov. 1995. The trees were planted in 1986-87 and had been fertilized and cultured in a similar manner prior to harvest. After harvest, the trees were baled and transported to Puyallup, Wash., on 17 Nov. 1994 and 28 Nov. 1995, where they were stored outside under shadecloth until they were set up and displayed indoors on 21 Nov. 1994 and 4 Dec. 1995. During storage at Puyallup, the minimum/maximum temperatures ranged from -4 to $9{ }^{\circ} \mathrm{C}$ in 1994 and -1 to $16{ }^{\circ} \mathrm{C}$ in 1995 .

Prior to setup, the trees were unbaled and trimmed to a height of 1.8 to $2.0 \mathrm{~m}$ in 1994 and 2.0 to $2.3 \mathrm{~m}$ in 1995 . Each year, five trees of each species were displayed dry and five were displayed with their freshly cut bases (2.5-5 $\mathrm{cm}$ trimmed from base) in water. To minimize differences in the initial moisture levels of the trees that were displayed dry and those that were displayed in water, a pressure chamber (Soilmoisture Equipment Corp., Santa Barbara, Calif.) was used to measure their water potential $(\psi)$ (Chastagner et al., 1984). The initial $\psi$ of the noble fir trees ranged from -1.1 to - 2.1 $\mathrm{MPa}$ in 1994 and -0.6 to $-1.1 \mathrm{MPa}$ in 1995. The initial $\psi$ of the Nordmann fir trees ranged from -0.9 to $-2.0 \mathrm{MPa}$ in 1994 and -0.5 to $-1.0 \mathrm{MPa}$ in 1995 . Trees were then paired with other trees that had a similar $\psi$. One tree from each pair was displayed with its base in an 18-L bucket of water and the other was displayed dry. The trees were set up in a large postharvest display room at Washington State Univ.-Puyallup that was maintained at $20 \pm 1.5^{\circ} \mathrm{C}$ and $\approx 55 \%$ relative humidity. The postharvest room was lit continuously with fluorescent lights (Sylvania Supersaver Cool White $60 \mathrm{~W}$ ). Trees were arranged in a randomized complete-block design with four combinations of species $\times$ display condition within each of five blocks.

During display, water was added to each bucket to ensure that the water level in the buckets was always maintained above the base of the tree. Changes in the moisture status of the trees were also monitored using a pressure chamber. In addition, the extent of needle loss during display was evaluated on two tagged branches per tree. The loss of current season and 1-year-old needles was rated on a scale of 0 to 10 : where $0=$ none; $1=1 \%$ to $10 \% ; 2$ $=11 \%$ to $20 \% ; \ldots$; and $10=>90 \%$ loss. The needle loss rating for the tree was the average of these two ratings. Overall tree quality was also rated on a scale of 1 to 5 : where $1=$ poor, unacceptable; 2 = fair; 3 = good; 4 = very good; and $5=$ excellent.

Data were subjected to analysis of variance using the statistical program SAS version 8 (SAS Institute, Cary, N.C.). The general linear models (GLM) procedure for repeated measurement analysis was used to determine if harvest year, display condition, and tree species had a significant effect on the moisture status, needle loss, and tree quality data.

\section{Results and Discussion}

Display condition had a significant effect on moisture retention, needle loss, and quality of the trees. When displayed in water, both species maintained high moisture levels $(\psi>-2 \mathrm{MPa})$ with minimal needle loss during the first 42 $\mathrm{d}$ they were displayed indoors (Fig. 1). Even after $70 \mathrm{~d}$ (data not shown), the noble fir had an average $\psi$ of $-3.2 \mathrm{MPa}$ in 1994 and -3.0 MPa in 1995, while the Nordmann fir had an average $\psi$ of $-2.8 \mathrm{MPa}$ in 1994 and $-2.2 \mathrm{MPa}$ in 1995. When displayed dry, both species also had similar rates of moisture loss, reaching a $\psi$ of $-6 \mathrm{MPa}$ in about $21 \mathrm{~d}$.

There was a significant difference between the species regarding the extent of needle loss that occurred when trees were displayed dry. Two of the Nordmann fir trees in 1994 and 1995 began to shed green needles within 3 to $5 \mathrm{~d}$ of being placed indoors. This corresponded to a $\psi$ of about $-3 \mathrm{MPa}$. These trees continued to lose large numbers of green needles during the next 7 to $14 \mathrm{~d}$. Unlike the Nordmann fir trees, very little needle loss occurred on any of the noble fir trees that were displayed dry, even when they had dried to a $\psi$ of $-6 \mathrm{MPa}$ (Fig. 1).

The noble and Nordmann fir trees that were displayed in water still had quality ratings $>4.0$ after $42 \mathrm{~d}$ of display. Even after 
$70 \mathrm{~d}$ (data not shown), the noble fir trees had an average quality rating of 3.2 in 1994 and 2.7 in 1995, while the Nordmann fir had an average quality rating of 3.9 in 1994 and 3.4 in 1995 . When displayed dry, the quality ratings decreased below 3.0 between 14 and 21 $\mathrm{d}$ of display for both species. The decrease in quality of the noble fir was a result of loss of color and drying of the needles. The decrease in quality of the Nordmann fir trees was due to the extensive loss of needles that occurred on two of the five trees, loss of color, and drying of the needles.

Except for the noble fir trees that were displayed in water, harvest year did not have a significant effect on moisture retention, needle loss, and tree quality (Figs. 1 and 2). In the case of the noble fir trees displayed in water, trees harvested in 1994 had a small but significantly lower $\psi$ than trees harvested in 1995 on about half of the days $\psi$ was measured.

After $42 \mathrm{~d}$, the extent of needle loss among individual Nordmann fir trees that were displayed dry varied extensively. During both years, two trees had needle loss ratings $>7$, while the other three trees had ratings that ranged from 0 to 2. Environmental conditions prior to harvest are known to affect needle retention by Fraser fir Christmas trees (Mitcham-Butler et al., 1987, 1988). With Fraser fir, needle retention is closely related to the dormancy status of the tree at the time of harvest. Nondormant trees lose large quantities of needles even when displayed in water. Even though there was very little difference in how the trees behaved during the 2 years these studies were conducted, further work is needed to determine the role of environmental and genetic factors in needle loss problems observed with Nordmann fir trees.

The Nordmann fir Christmas trees in these studies did not have the same postharvest needle retention characteristics as noble fir Christmas trees when they were displayed dry. Limited loss of needles and slow rates of drying are important factors that affect the postharvest quality and safety of Christmas trees. Unless growers, wholesalers, retailers, and consumers are able to care for trees in such a way that minimizes moisture loss from cut trees, our data indicate that the industry and consumers are likely to experience increased needle loss problems associated with the increased production of Nordmann fir Christmas trees.

Critical moisture contents (Van Wagner, 1963) and damage thresholds (Montano and Proebsting, 1986) have been identified for a number of Christmas tree species (Chastagner, 1986; Hinesley, 1984; Hinesley and Snelling, 1988, 1995, 1997; Montano and Proebsting, 1985, 1986, 1988; Seiler et al., 1988). Allowing harvested trees to dry below their damage threshold can result in a significant increase in needle loss. Although additional data are needed, the results from these studies suggest that Nordmann fir trees have a damage threshold around $-3 \mathrm{MPa}$, which is a slightly higher $\psi$ than the damage threshold for Douglas-fir [Pseudotsugamenziesii (Mirb.) Franco] Christmas trees (Chastagner, 1986; Montano and Proebsting, 1985).

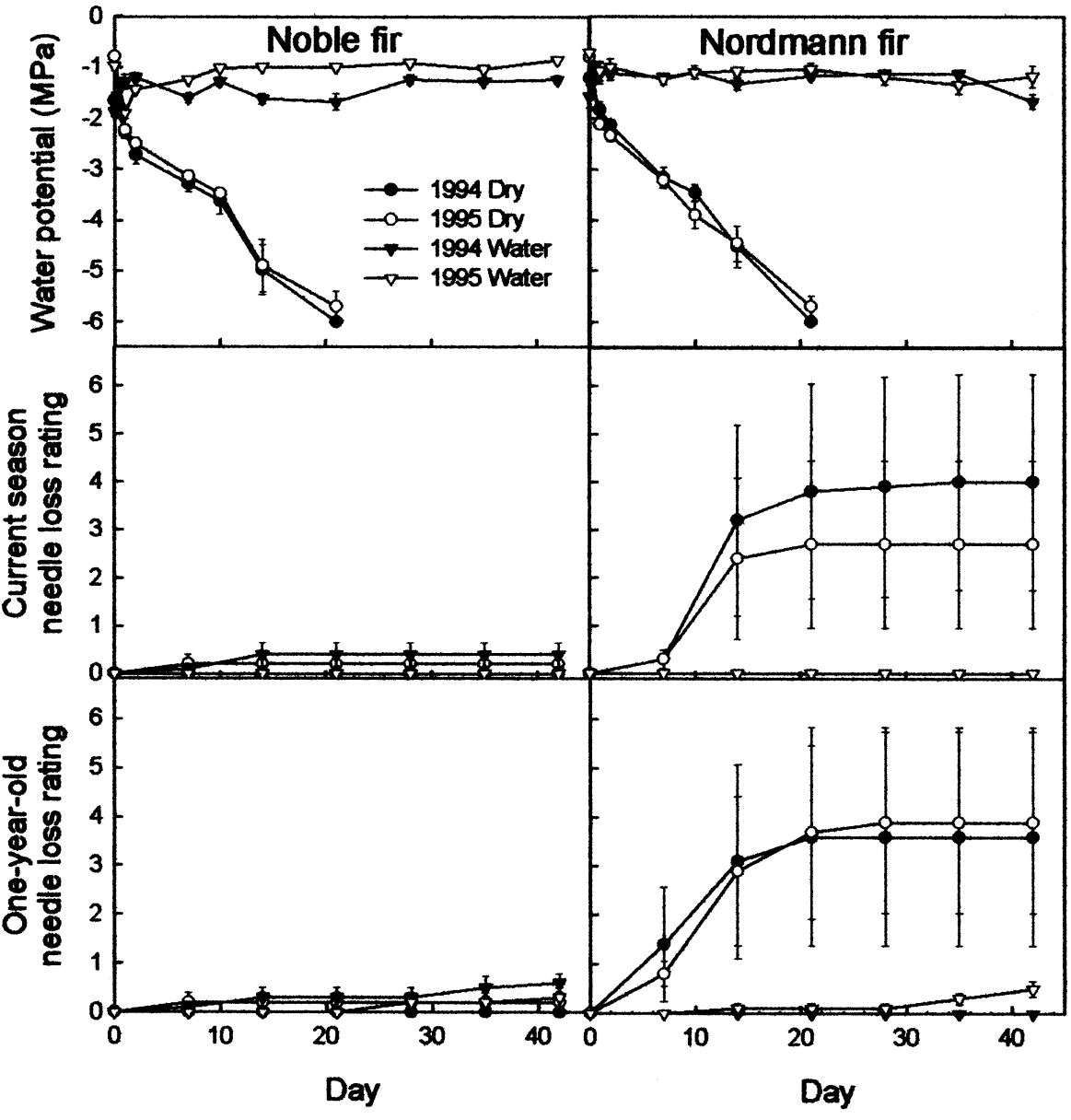

Fig. 1. Effect of display condition (in water vs. dry) on the moisture status and needle retention by noble and Nordmann fir Christmas trees that were displayed indoors at $20^{\circ} \mathrm{C}$. Needle loss was rated on a 0 to 10 scale: where $0=$ none and $10=>90 \%$ loss. Data points represent means $(n=5)$ with standard error bars.

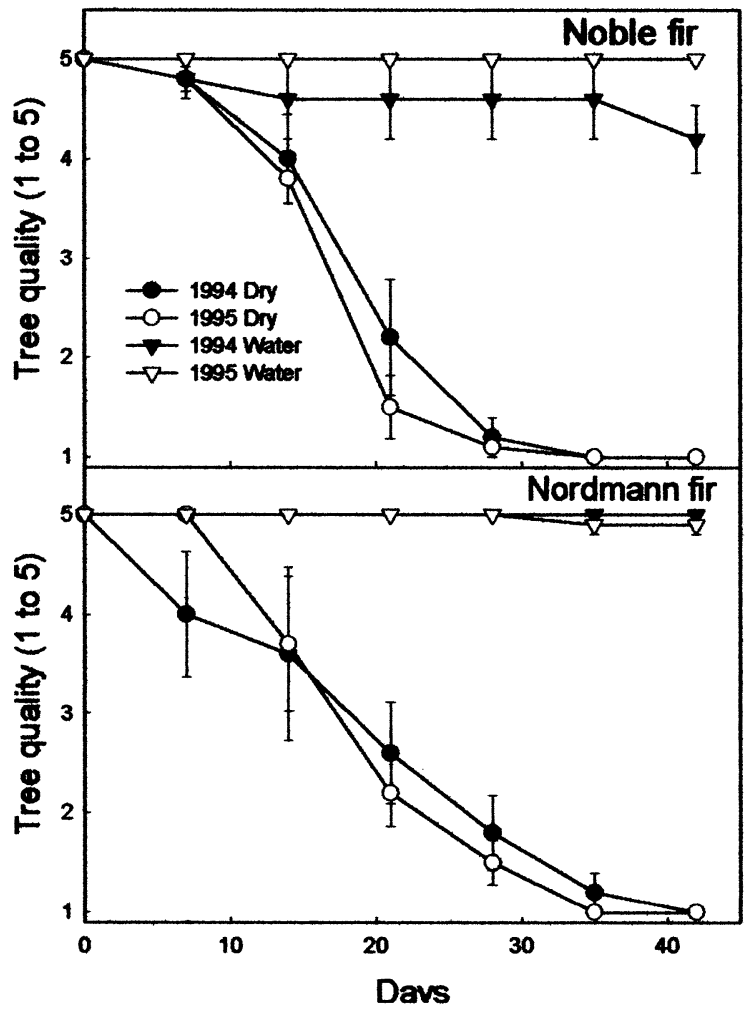

Fig. 2. Effect of display condition (in water vs. dry) on the overall quality of noble and Nordmann fir Christmas trees that were displayed indoors at $20^{\circ} \mathrm{C}$. Tree quality was rated on a 1 to 5 scale: where $1=$ poor, unacceptable; $2=$ fair; 3 = good; 4 = very good; and $5=$ excellent. Data points represent means $(\mathrm{n}=5)$ with standard error bars. 
Denmark is the leading producer of Nordmann fir Christmas trees in Europe (Frampton and McKinley, 1999). Most of the trees produced in Denmark are exported to other European countries. As Danish production has increased and more trees are exported, there have been reports in some markets of needle loss problems (British Christmas Tree Growers Assn., 1991, 1992). Our data indicate that these problems are likely the result of drying during the shipment, handling, and display of trees. For consumers, our studies indicate that displaying Nordmann fir in water is an effective way to minimize needle loss problems with this species.

Given that some of the Nordmann fir trees that were displayed dry had excellent needle retention, it may be possible to identify sources of Nordmann fir that do not shed needles upon drying. Recent work in Denmark (Nielson and Chastagner, unpublished) indicates that needle retention is a highly heritable characteristic, thus providing good possibilities to improve the postharvest quality of Nordmann fir through a selection and breeding program.

\section{Literature Cited}

Bean, W.J. 1981. Trees and shrubs hardy in the British Isles. Vol. 1, 8th ed. St. Martin's Press, New York.

Benson, D.M., L.E. Hinesley, J. Frampton, and K.C. Parker. 1998. Evaluation of six Abies spp. to Phytophthora root rot caused by Phytophthora cinnamomi. Biol. and Cult. Tests for Control of
Plant Dis. 13:57.

British Christmas Tree Growers Assn. 1991. Marketing-Christmas 1990. British Christmas Tree Growers Assn. Nwsl. No. 16 (April).

British Christmas Tree Growers Assn. 1992. Christmas tree market 1991. British Christmas Tree Growers Assn. Nwsl. No. 18 (April).

Chastagner, G.A. 1986. Effect of postharvest moisture stress on the keeping qualities of Douglas-fir Christmas trees. HortScience 21: 485-486.

Chastagner, G.A. and D.M. Benson. 2000. The Christmas tree: Traditions, production and diseases. Plant Health Progr: Accession DOI 10.1094/PHP-2000-1013-01-2V.

Chastagner, G.A., R.S. Byther, J.D. MacDonald, and E. Michaels. 1984. Impact of Swiss needle cast on postharvest hydration and needle retention of Douglas-fir Christmas trees. Plant Dis. 68:192-195.

Chastagner, G.A., K.L. Riley, and P.B. Hamm. 1990. Susceptibility of Abies spp. to seven Phytophthora spp. Phytopathology 80:887.

Frampton, J. and C. McKinley. 1999. Christmas trees and greenery in Denmark-Production and tree improvement. Amer. Christmas Tree J. 43(2):4-11.

Hinesley, L.E. 1984. Measuring freshness of cut Fraser fir Christmas trees. HortScience 19: 860-862.

Hinesley, L.E. and L.K. Snelling. 1988. Water relations of cut eastern redcedar Christmas trees. HortScience 23:589-591.

Hinesley, L.E. and L.K. Snelling. 1995. Postharvest drying of Leyland cypress, eastern red cedar, and Fraser fir Christmas trees. HortScience 30: 1427-1428.

Hinesley, L.E. and L.K. Snelling. 1997. Postharvest drying and rehydration of Leyland cypress, Atlantic white cedar, Virginia pine, Arizona cypress and eastern white pine Christmas trees. HortScience 32:1252-1254.

Jakobsen, F. 1988. Juletræer og klippegrønt, p. 607-636. In: H.A. Henriksen (ed.). Skoven og dens dyrkning. Dansk Skovforening. Ny Nordisk Forlag Arnold Busk, København.

Løfting, E.C.L. 1973. Statusopgørelse for nordmannsgran (A survey of the present state of Caucasian fir in Denmark). Forstl. Fors $\emptyset$ gsv. i Danm. 33(3):305-326.

Mitcham-Butler, E.J., L.E. Hinesley, and D.M. Pharr. 1987. Soluble carbohydrate concentration of Fraser fir foliage and its relationship to postharvest needle retention. J. Amer. Soc. Hort. Sci. 112:672-676.

Mitcham-Butler, E.J., L.E. Hinesley, and D.M. Pharr. 1988. Effects of harvest date and storage temperature on the postharvest needle retention of Fraser fir branches. J. Environ. Hort. 6(1):1-4.

Montano, J.M. and W.M. Proebsting. 1985. Effects of drying on cut Douglas-fir. J. Amer. Soc. Hort. Sci. 110:751-754.

Montano, J.M. and W.M. Proebsting. 1986. Storage of cut Douglas-fir: Relationship to the damage threshold. HortScience 21:1174-1175.

Montano, J.M. and W.M. Proebsting. 1988. Development of the abscission zone in needles of Douglas-fir. J. Amer. Soc. Hort. Soc. 113: 133-137.

Seiler, J.R., T.J. Nichols, and D.J. Paganelli. 1988. Rehydration characteristics of cut white pine and Norway spruce Christmas trees. HortScience 23: 164-166.

Van Wagner, C.E. 1963. Flammability of Christmas trees. Canada Dept. For. Publ. 1034, Ottawa, Canada. 